\title{
Of Spirit and Europe: What Derrida Missed
}

\section{Timo Miettinen}

Centre for European Studies, University of Helsinki, 00014 Helsinki, Finland; timo.pa.miettinen@helsinki.fi

\begin{abstract}
This article deals with Jacques Derrida's critique of the phenomenological concepts of spirituality and spirit, particularly in the context of his 1987 book Of Spirit. As the article shows, Derrida's interpretation of these concepts was based on a seemingly minor, yet extremely important misreading of Edmund Husserl's key passages on the relationship between spirituality and Europe. Unlike Derrida claims, Husserl did not equate Europe with the universal teleology of humankind. Instead, what the concept of spirituality opened up was a new way of understanding transcendental modes of experience as embedded in a particular historical situation of a particular community. Philosophy, understood as a "spiritual" phenomenon, denoted for Husserl a fundamentally intersubjective and intergenerational phenomenon that is by no means separate from empirical history.
\end{abstract}

Keywords: Europe; spirit; phenomenology; Derrida; Husserl; teleology; ideality

Jacques Derrida's book De l'espirit (Of Spirit) appeared in 1987. Because Derrida was at the top of his popularity in the Anglophone world, the book was quickly translated into English (Derrida 1989) and deservedly extolled for being one of the most interesting contributions to the ongoing debate on Heidegger's relation to National Socialism. In the late 1980s, the debate on Heidegger's political commitments had gained new attention with the publication of Victor Farias' Heidegger et le nazisme (1987) and François Fédier's Heidegger: Anatomie d'un scandale (1988), both of which relied on a rather straightforward equation between Heidegger's philosophy and fascism. Derrida's work-originally consisting of a lecture delivered at the CIPH conference titled "Heidegger: Open Questions" - was likewise critical, but it was also able to counter some of the obvious misconceptions related to Heidegger's political commitment. As Derrida argued, it was with the help of the concepts of "spirituality" or "spirit", which Heidegger employed from his 1933 Rectoral Address onwards, that he was able to reject the evident biologism and racism of the National Socialist movement. In Derrida's view, by emphasizing the "spiritual roots" of the German people, Heidegger was able to link the task of the German people to a wider task of European "civilization". This was naturally in clear contrast to Nazi ideology.

This use of the concept of spirit, however, could not be done without the appearance of new "ghosts" or "ashes"-Derrida's poetic metaphors for that which remains unthought. Instead, what the vocabulary of spirituality carried within itself was nothing less than the metaphysical ideal of Western metaphysics, that is, being as absolute and constant presence. Instead of beings, there is ultimately only being that is absolute, transcendent, and irreducible. All variation is fundamentally flickering and all particularity perishable and transient.

In the field of history, the idea of the spirit contained within itself the whole framework of teleological universal history and the idea of European exceptionalism that was a central part of German idealist philosophy: Kant, Fichte, and Hegel in particular. To say that history is guided by spirit means not only that it is righteous, but that it is fundamentally tied to the idea of a single end. Despite the differences in their approaches, they all employed the vocabulary of spirituality to alleviate the basic preconception of modern historical consciousness: history, despite its variations, is eventually on the side of freedom and reason. This connection is secured through political institutions that are characteristically European, and as in the case of Fichte and Hegel, primarily German (see Kleingeld 2012). 
Derrida's criticism was not restricted only to Heidegger. This teleological-historical Eurocentrism was also evident in Edmund Husserl's vocabulary of spirit and Europe, for instance, in what Husserl called Europe's "spiritual geography" and its "spiritual historicity". In a lengthy footnote to Of Spirit, Derrida questioned Husserl's rather odd demarcation of "spiritual Europe" as including the United States and the English dominions yet excluding the "Eskimos" and "Indians" on display at fairs (die Eskimos oder Indianer der Jahrmarktsmenagerien) and the "gypsies" that are constantly on the move. According to Derrida, Husserl fell victim to that same philosophical chauvinism as Heidegger. Both delineated the "transcendental teleology of reason as Europocentric humanism" (Derrida 1987, p. 121).

This critique had already been articulated in Derrida's early works, most importantly, in his first book-length work The Problem of Genesis in Husserl's Philosophy (originally a dissertation for the completion of diplôme d'études supérieures in 1954) and to a lesser extent in the 1962 introduction to Husserl's late essay "Origin of Geometry". It appeared once again in the 1991 essay L'autre cap (The Other Heading) that linked the Husserlian crisis of the European spirit to the modern tradition of historical eschatology from Hegel to Fukuyama—an eschatology that treated "Europe" as the "head" or "heading" (cap) "for world civilization or human culture in general" (Derrida 1992, p. 24). "From Hegel to Valéry, from Husserl to Heidegger", Derrida writes,

[...] this traditional discourse [on Europe] is already a discourse of the modern Western world. [...] It dates from a moment when Europe sees itself on the horizon, that is to say, from its end (the horizon, in Greek, is the limit), from the imminence of its end. This old discourse about Europe, a discourse at once exemplary and exemplarist, is already a traditional discourse of modernity. (Derrida 1992, p. 28)

In Derrida's view, the fact that Husserl, too, approached the history of Europe with the vocabulary of spirit, meant that he was inevitably bound to the general framework of universal history within which Europe was treated as the high point of historical development. Moreover, this development was fundamentally marked by the idea of necessity as the key organizing principle of historical reality. Philosophy, according to this critical view, simply became an explanation ex post facto on the historical development of Europe-its conquests and historical wrongdoings. What could be more Eurocentric?

This article aims at answering Derrida's criticism from a Husserlian perspective. It does so not only from a purely exegetical point of view but to highlight the importance of the often neglected thematic of spirituality in Husserl's thinking of Europe. As I argue, Husserl did not employ the concepts of spirit (Geist) and spirituality (Geistlichkeit) to dismiss the material or geopolitical aspects of Europe. Nor were they introduced as yet another variation of the historical determinism characteristic of modern thought. Rather, the vocabulary of spirituality that Husserl employed from the late 1910s onwards pointed towards a broadened understanding of transcendental subjectivity and its constitution. This took place in the double sense of the genitive: first, as the "genetic" or temporal constitution of this subjectivity understood as the process of habituation, and secondly, as the temporal process of sedimentation characteristic of constituted objectivities. Most importantly, the notion of spirit and spirituality played an important role in the development of Husserl's concept of the lifeworld (Lebenswelt) as that necessary horizon that founds all types of cultural objectivities, and thus, serves as the ground for the development and demarcation of cultures as such.

The "spirituality" of the lifeworld, however, did not entail a complete break from the material conditions of a given environment; rather, it served as the central concept for that process of invigoration and normative demarcation based on which the material world acquires its sense of familiarity or alienness.

Unlike Derrida insisted, Husserl's notions of "spiritual Europe" or "spiritual geography" did not entail a complete break with cultural and political processes of limit formation, nor did they simply coincide with the historical inevitability characteristic of German ide- 
alism. Rather, what the idea of "spiritual Europe" denoted was nothing less than the necessary intertwining of matter and spirit, of "geography" and "history of ideas". Philosophy, too, has its origin in the lifeworld, and as a concrete practice, to use the Derridean expression, it is always "contaminated" with the empirical. However, neither does this vocabulary of spirituality condemn us to the deterministic and eschatological outlook of modern universal history. For Husserl, what the domain of spirituality-particularly, the type of spirituality characteristic of philosophical accomplishments-opened up was essentially a whole new dimension of infinity or inexhaustibility, a way out of the eschatological outlook of the 19th- and early 20th-century philosophy of history.

\section{Derrida and Husserl's Spirit}

Derrida's criticism of Husserl's Eurocentrism appeared in several of his works. Its earliest expression, however, is to be found in the 1954 dissertation The Problem of Genesis in Husserl's Philosophy, one of the earliest appreciations of the topics of temporality and genesis in Husserl's works. Since Derrida's analysis on the concept of spirit is fundamentally tied to the problem of genesis, let us first focus on this notion.

Husserl introduced the concept of genesis in relation to a new methodological opening in the 1920s: the idea of genetic phenomenology (Husserl 1966, p. 336ff.; Husserl 1973c, pp. 34-43). In contrast to the so-called static phenomenology investigating "the general structures and modalities that encompass all categories of apprehensions", Husserl began to develop "a universal theory of genesis" that was supposed to study these structures with regard to their process of origination. Thus, the problem of genesis introduced a wider understanding of the formation of meaning. In distinction from Husserl's earlier analyses on intentionality that had focused on the correlation between subject and the world-how different types of intentionality differ from each other-the genetic analyses focused on the dynamic character of this process. Husserl wanted to understand how different types of acts and intentional relations presuppose and follow each other. How do individual modes of constitution turn into permanent modes of directedness to the world? How do acts turn into attitudes?

Husserl defined genetic analyses as "explanatory" (erklärende) in distinction from the "descriptive" (beschreibende) statements characteristic of static phenomenology. The genetic analyses did not simply describe different forms of experience; their aim was to clarify those conditions based on which different types of experience emerge at a certain point of time and why (Husserl 1966, p. 340). The question was not so much about causal relations but relations of motivation, that is, those ideal conditions that enable the constitution of meaning in the first place.

Husserl employed the concept of teleology (Teleologie) to describe the general structure of this process. This concept, however, was not to be understood in terms of a ready-made telos in the manner of Aristotelian teleology describing a linear process of development (Husserl 1966, p. 339). Neither was teleology to be understood in the manner of German idealism, as a predetermined goal. For Husserl, teleology referred primarily to the synthetic or associative structures of conscious life. Our consciousness is "teleologically oriented" because we experience the world around us as structured and harmonious: our perceptions have as their telos the constitution of complete objects (Husserl 1973a, pp. 12-13; Husserl 1950, p. 213). In this regard, Husserl understood the concept of teleology as the "form of all forms", as that overall structure of constitution that we are all the time living through (Husserl 1973d, p. 380). To say that our conscious life is teleological is to say that it has a history and is oriented to the future.

Derrida's basic attitude towards genetic phenomenology was positive. What he found in genetic phenomenology was a new way of confronting the accusation on the fundamentally "static" character of phenomenology — an accusation that Theodor Adorno had proposed already in the 1930s. At that time, Husserl's reputation was still that of a Platonist, particularly with regard to his theory of ideas. Although many of Husserl's contemporaries appreciated the new approach to the problem of ideality in the Logical Investigations-ideas, 
too, are founded on immediate experience through categorical intuition-and employed it for legal theory (e.g., The Vienna School of jurisprudence) or new, rigorous economics (e.g., The Freiburg School of ordoliberalism), this approach was quite often seen as inadequate in capturing the essentially historical character of cultural objectivities and idealities. Many of Husserl's contemporaries, when speaking of things such as language, religion, science, or art, resorted to concepts other than ideality (e.g., "symbolic forms"). Derrida, however, acknowledged Husserl for his attempts in overcoming the objectivist and historicist criticisms of ideality. Ideas do have a history, a genesis, but this does not mean that they would simply be relative. In Derrida's view, Husserl had rescued the vocabulary of ideality and genesis from both empirical psychologism and naturalist biologism and made it philosophically relevant.

This operation, however, had its costs. In Derrida's view, Husserl's insistence on discovering the ideal genesis or "transcendental teleology" was founded on a premise of purity and universality far too ambitious for the kind of experience that the analysis of temporality had revealed. If this original process of temporalization was always already mine, always bound to a particular subject and its genesis (with a particular historical situation, etc.), how could Husserl insist on locating a purely transcendental level of investigation within genetic phenomenology? Did not the very idea of time-consciousness, understood as the source of individuation for the transcendental ego, reveal important empirical constraints at the heart of phenomenological reflection? After all, this was the very reason why Kant located the problem of temporality within the domain of the empirical ego instead of the transcendental one. Thus, this idea of transcendental teleology, Derrida argued, "saved phenomenology by contradicting it" (Derrida 2003, p. 153). After this turn towards the genetic method, Husserl could no longer hold on to the purely transcendental or ideal character of phenomenology and its basic concepts; rather, the domain of transcendental was "contaminated" (contaminé) by empirical factors. This insight, then, became a central starting point for Derrida's later works; most importantly, Voice and Phenomenon (Derrida 2011).

In The Problem of Genesis, however, Derrida's focus was still on the symptoms of Husserl's contradictory discourse. Out of these symptoms, it was exactly the problem of Europe that received the most prominent attention. For Husserl, the question of Europe emerged during the 1930s as a response to the contemporary crisis of Western civilizationa crisis that appeared as a demise of universal, philosophical reason in the face of growing naturalism and historical relativism. Following Galileo's "fateful omission", the natural sciences had removed the concept of teleology altogether from the domain of scientific reason. Thus, modern science had turned categories of value and purposefulness into mere subjective phenomena. For this reason, Husserl needed to return backward (what he called rückfragen) from this state of confusion into the roots of modern rationality, and even further, into the very origins of our Western scientific reason: the birth of Greek philosophy. While the history of Europe could not simply be reduced to the history of philosophy-for instance, Husserl treated the question of Europe's "political historicity" as a topic of its own - it was exactly philosophy whose new vocabulary of ideality opened up a completely new horizon of development for the European culture, that of an "infinite task". For the first time, it was possible to imagine such a horizon of production and action that could not be exhausted by a single era but that could be seen as stretching from one generation to the other, unbroken and uninterrupted. However, it was exactly this completely new teleological horizon-"the revolutionization (Revolutionierung) of the whole culture" (Husserl 1976, p. 25)—that had been lost by the moderns. For this reason, Husserl's quest for Europe was fundamentally a quest for the revitalization of the fundamental motive or "original institution" (Urstiftung) of Greek philosophy.

Thus, for Husserl, philosophy was, at the same time, both an idea as well as an existing tradition. It was an idea insofar as it denoted the insistence of full responsibility for one's own "presuppositions" (Voraussetzungen) such as beliefs, values, and practices. However, 
it was also a tradition with a distinct origin (Greece) and an existing heritage (medieval and modern philosophy).

It was exactly here that Derrida's criticism entered the picture. If the idea Europe had only one "spiritual birthplace", as Derrida understood Husserl, how could this idea be understood without tracing it back to empirical history? How could Husserl still insist on the purely ideal character of Europe when it is clearly born in a certain place and time? As Derrida concludes, for Husserl "the idea of philosophy is thus reduced to a fact" (Derrida 2003, p. 156) -what appeared as a purely ideal construction appears as an empirical fact. Husserl's delineations of the "spiritual geography" of Europe, Europe as a "spiritual figure", were fundamentally nothing but expressions of this paradox. They revealed the impossibility of reconciling the transcendental character of philosophy with its empirical history beginning with Plato and Aristotle.

In Derrida's view, however, the idea of "spiritual geography" was problematic not only because of its empirical constraints, but also because it produced a rather strange division between European and non-European cultures. By locating the transcendental idea of philosophy in a particular historical event, Husserl seemed to split the idea of humanity into two separate domains: "the spiritual family of Europe" and the "families of an empirical type" (Derrida 2003, p. 159). In Derrida's analysis, this division between transcendental and empirical humanity was the same as that of teleological and non-teleological cultures. In this view, there are cultures defined by a single teleological horizon and cultures that, as many of the classic anthropologists would have put it, have no common memory, no shared history (a topic that Husserl discussed especially with the French anthropologist Lucien Lévy-Bruhl). This Husserlian hypothesis, Derrida argued, was of course simply "laughable" (Derrida 2003, p. 157). For him, it was the only way to understand Husserl's distinction between the "immanent teleology" of Europe and the "empirical sociological types" such as India and China that Husserl referred to in the Crisis and its supplements.

However, this was not exactly Husserl's argument. As a careful textual analysis shows, while Husserl analyzed the "spiritual form" of Europe with the concept of teleology, he did not restrict the concept of teleology only to Europe. Derrida's reference to Husserl's "reworked text of the Vienna Lecture"- - seule l'Europe a une "téléologie immanente»", "only Europe has an 'immanent teleology'" (Derrida 2003, p. 157)—was not taken from Husserl's original text but from Paul Ricoeur's 1949 article "Husserl and the Sense of History". This article contained two erroneous translations of the Vienna Lecture (Ricoeur 1967, p. 152). In this article, Husserl made a reference to what he called "nur unserem Europa gleichsam eingeborene Teleologie" (Husserl 1976, p. 318)—a teleology that is born only within our Europe. Secondly, he referred to that philosophical idea which is immanent to European history: "Die der Geschichte Europas (des geistigen Europas) immanente philosophische Idee aufzuweisen, oder, was dasselbe ist, die ihr immanente Teleologie [...]" (Husserl 1976, p. 318). As any careful reader can see, Husserl did not see "immanent teleology" as something that belongs only to European culture. Rather, what made the immanent teleology of Europe unique was its type or character. It was only in Europe that the teleology of culture was defined by an infinite horizon of development.

In addition to this, Derrida's reference to the "empirical sociological types" such as China and India was inaccurate-it does not appear in Husserl's works. In the first part of the Crisis, Husserl distinguished between the "absolute idea" of culture and the "empirical anthropological types" of which China and India were given as examples (Husserl 1976, p. 14). This distinction, however, was not to be understood as a classification of cultures. As it is evident from the original German text, what Husserl laid out was a difference in approach: while teleology can only be approached from the perspective of internal historicity, anthropological typification is a fundamentally objectivist, third-person category. In the Vienna lecture, for instance, Husserl makes an explicit reference to Indian historicity (die indische Geschichtlichkeit) and its peculiar teleology. They can be understood on the basis of accomplishments such as texts and works of art (Husserl 1976, p. 321). For Husserl, teleology was not simply a European idea. 
This accusation regarding Husserl's alleged Euro-centrism was articulated also in Derrida's later works. In Of Spirit, Derrida interpreted Husserl's teleological analysis of Europe - the idea of Europe as a "spiritual form" — as belonging to historicist tradition as German idealism. Imagined as the unity of a rational tradition, Derrida argued, Husserl's Europe became a purely "spiritual" phenomenon that was independent of any geographical or geopolitical divisions. As in the case of Hegel's definition of Europe as "the elevation of the particular to the universal" (Hegel 1975, p. 173), Husserl's Europe, Derrida argued, was no longer "assigned a geographical or territorial outline" (Derrida 1987, p. 95). (It is somewhat unfortunate that Derrida did not have the chance to consult volume 29 of Husserliana, which speaks of the "spiritual space (Raum) of Europe".) As Derrida argued, this spiritual geography was by no means indifferent to the cultural or ethnic divisions of Husserl's time. According to Husserl's controversial analysis, the "spiritual-geographical" definition of Europe included the United States, the English Dominions, and even Japan, which Husserl, in one of his manuscripts, described as a "fresh branch of European culture" (Husserl 1988, p. 95). The notion of spirit, rather than serving as the guardian of universal humanism, played "a major organizing role in the transcendental teleology of reason as Europocentric humanism" (Derrida 1987, p. 121).

This criticism was also the point of departure for Derrida's 1991 article "The Other Heading" (L'autre cap). In this text, Derrida distanced himself from the "arche-teleological" narrative of Husserl, Hegel, and Heidegger-a narrative that projected the "spiritual unity" of Europe through a predetermined idea of beginning and end. This narrative, Derrida argued, dated "from a moment when Europe sees itself on the horizon, that is to say, from its end [...], from the imminence of its end" (Derrida 1992, p. 28). As such, it represented one of the most "destructive traits" of modern philosophy. By outlining the development of European history in terms of an imminent end-the end of "history" (Hegel), of "philosophy" (Heidegger), of "European spirit" (Valéry) — this arche-teleological approach condemned itself to a historical narrative that was both monolithic and hermetic. Moreover, it was a way to dismiss "other headings" that ascend within this tradition. Accordingly, it did away with the possibility of redefining the ideals of culture through an encounter with the other.

To fully understand Derrida's point, however, we need to take a closer look at those motivations that led Husserl to understand the problem of culture, and particularly that of Europe, in terms of spirit.

\section{Husserl: Spirit and Generativity}

To appreciate the central role of the concept of spirit in Husserl's late works, let us take a look at a passage from the Vienna lecture of 1935:

Spiritual Europe has a birthplace. By this I mean not a geographical birthplace, in one land, though this is also true, but rather a spiritual birthplace in a nation or in individual men and human groups of this nation. It is the ancient Greek nation in the seventh and sixth centuries BC. Here, there arises a new sort of attitude of individuals toward their surrounding world. Additionally, its consequence is the breakthrough of a completely new sort of spiritual structure, rapidly growing into a systematically self-enclosed cultural form; the Greeks called it philosophy. (Husserl 1976, p. 321)

From the perspective of Husserl's works, the recurrent use of the concept of "spiritual" (geistig) may appear somewhat surprising. The concept was basically absent from Husserl early works (those between 1890 and 1917), but appeared several times in Husserl's manuscripts on intersubjectivity, personality, and the lifeworld, beginning from Ideas II (under the title "Constitution of the Spiritual World") and the 1919 lecture course "Nature and Spirit" (Natur und Geist). ${ }^{1}$ Especially in Husserl's texts on Europe, we find this term in the recurring formulations of "the spirit of Europe", "spiritual Europe" and its "spiritual geography", its specific "spiritual form", and the "spiritual culture" animating its history. ${ }^{2}$ In the Crisis, this emphasis on the spiritual was turned into an almost Hegelian analysis 
of the spiritual world: "The spirit, and indeed only the spirit, exists in itself and for itself, is self-sufficient [...] for the spirit alone is immortal" (Husserl 1976, pp. 345-48). This emphasis seemed to question the personalistic and concrete character of phenomenological descriptions. ${ }^{3}$

Why did such a transition occur? In the second volume of Ideas, Husserl originally introduced the concept of spirit in relation to two different domains of constitution, that of material nature and that of "animal" or "psychic" (seelische) nature. As Husserl noted, it was the distinction between "nature" and "spirit" on the one hand, and between "soul" and "spirit" on the other, that "determine our entire world-view, essentially and fundamentally" (Husserl 1952, p. 172). Husserl was quick to refute the idea according to which these three domains could be distinguished simply in terms of their subject matter (e.g., stones, plants/animals, human beings). The (human) subject, for instance, is at the same time "nature" (or a "natural being") and a person ("psychic being"), as well as "a part of the social world", someone who constitutes for itself a "world of spirit".

In this regard, Husserl spoke of "spiritual nature" (geistige Natur) as a kind of "complex" that is composed of the lower strata of material and animal nature (Husserl 1952, p. 29). We constantly see nature as being "spiritualized" (vergeistigt), as something that incorporates (verkörpert) all kinds of historical, religious, and cultural meanings. ${ }^{4}$ This does not mean, however, that all of these would simply be a part of material nature. Pure geometry, for instance, is an accomplishment that can only be grasped as a field of ideal relations. Still, even geometry has its basis in those natural formations that characterize our lifeworld, shapes that can further be idealized into pure forms such as lines and circles.

It seems evident, then, that the concept of spirit was to be understood in close connection to the topic of intersubjectivity and culture. As Husserl wrote: "For every subject that in this way is a member of a social association as a totality, there is constituted the same world of spirit" (Husserl 1952, p. 197). The concept of spirit was to be understood as being both the animating principle of cultural objectivity as well as the key principle of what Husserl called the "communal spirit" (Gemeingeist) of interpersonal associations. In this regard, phenomenology could no longer articulate itself in the Cartesian-Kantian vocabulary of ego, consciousness, and subjectivity. Instead, it needed to engage itself with the concept of spirit, referring to the fundamentally communal and historical aspects of meaning and validity. ${ }^{5}$

Spirit, understood in this communal and temporal sense, constituted nothing less than the basic principle of generativity (Generativität), the field of historical, cultural, and intergenerational processes of meaning creation. This concept, for Husserl, denoted nothing less than the "unity of historical development in its widest sense" (Husserl 1992, p. 63), that is, those forms of meaning creation that take place in intergenerational forms of cooperation and produce lasting results. These forms range from simple cultural practices such as handicraft to political and social institutions, religious practices, and scientific enterprise. Although they are fundamentally different from each other, they all share the common structure of traditionality in the sense that they are passed forward (Lat. tradere) over the course of generations. Thus, they all have their origin and future horizon of expectation beyond the life of the individual person. From this perspective, the concept of generativity significantly broadened the scope of phenomenology to also include those forms of meaning that are appropriated on the basis of a pre-existing tradition-its imitation, assimilation, or refutation.

In this regard, the concept of spirituality did not entail an "idealistic" position. On the contrary, it was used to emphasize the inherently "realist" dimension of culture. It was with the help of the concept of spirit that Husserl was able to articulate a conception of culture that is fundamentally tied to material nature-and that finds its true platform in the life of the community. Spirit was that principle of transgression through which the reciprocal understanding characteristic of communities articulates itself in the domain of culture and in the natural world. 
Thus, while Husserl often emphasized that the idea of "spiritual Europe" was indeed something else than the typical objectivist understanding of this concept ("Europe, not as it is understood geographically, as on a map" (Husserl 1976, p. 318), this, unlike Derrida thought, did not mean complete separation from material reality. In this communal and cultural sense, the very idea of territoriality was to be conceived of as a "spiritual" category that demarcates the difference between home and alien, of familiarity and strangeness (Husserl 1973d, p. 206). However, it is only some natural constructions that contain within themselves a spiritual meaning and demarcate a boundary between home and alien. For the Romans of the 2nd century, it was the rivers Danube and Rhine that separated the Romans from Germanic tribes-Tiber united them under their common settlement. All cultures, not just Europe, are defined by a "spiritual geography" insofar as they are defined by territoriality and a sense of familiarity.

In Husserl's view, what was specific about Europe was the type and character of this spirituality.

\section{Philosophy and Generativity}

Husserl's early works approached the idea of philosophy primarily in terms of an individualistic attitude or praxis. The beginning of philosophy, according to this account, was to be conceived of as a peculiar conversion from the everyday experience of the natural attitude (the world as a "habit" as Fink often emphasized) to that type of posture that examines the world in its process of becoming real, actual, and meaningful in the life of the consciousness. Personal responsibility, rather than inherited theories, was to be set into the heart of philosophical reflection.

While Husserl never gave up on the significance of this responsibility, his later worksparticularly The Crisis and its respective manuscripts-point towards a slightly different direction. Philosophy, as Husserl came to understand it, could not be captured in its essence simply by abstaining from the inherited tradition of ideas; rather, the history of philosophy itself acquired a new meaning as the necessary point of departure for philosophical work as a whole.

As several manuscripts from the 1930s indicate, this insight was based on Husserl's broadened understanding of the birth of philosophy in the Classical era. Instead of focusing on this event in individualistic terms — as he had done in the lectures of the 1920s-Husserl began to approach this event also as a generative phenomenon, that is, as a communal and cultural undertaking. This transition had significant implications for the idea of political community. Philosophy, rather than appearing as a completely unexpected posture of exceptional individuals such as Socrates, was to be understood on the basis of a series of cultural, historical, and geopolitical transformations that characterized the Greek or Mediterranean city-states in the wake of the Classical era. ${ }^{6}$ Unlike Derrida claimed, however, this did not entail that philosophy as such could be reduced to an empirical fact; instead, these events were to be captured in their ideal features, as transitions in the ideas of lifeworld and tradition.

In one of his late manuscripts, "Teleology in the History of Philosophy", Husserl emphasized the role of myth critique as being constitutive for the theoretical attitude. "The Greeks were keen to despise the barbarians", Husserl wrote, "the alien mythologies that signified such an important dimension of the practical environment in the alien as well as in the own people, and [they] considered them even as barbaric, stupid, or profoundly wrong" (Husserl 1992, p. 387). ${ }^{7}$ Even this mockery did not do away with the fascination for the similarities and analogous ways of seeing the world, "the same sun, the same moon, the same earth, the same sea, etc." (Husserl 1992, p. 387). In addition to the kind territorial myths characteristic of particular cultural worlds, the Greeks gave birth to a new kind of interest in "universal myths", referring to common features of the lifeworld such as the earth and heavenly bodies (Husserl 1992, pp. 43-44). In one of his late manuscripts, Husserl called this process that of "demythologization" (Entmythisierung). ${ }^{8}$ Through the overcoming of particular cultural ways of seeing the world, this critique fostered what 
Husserl called the "first objective world"(erste objektive Welt), a world divested of the primacy of a particular homeworld (Husserl 1992, p. 45).

Now, although this idea of an objective world was conceived only as a "vague notion""all-communal ground for all identifications"-it presented a challenge for the "naïvenatural historicity of human existence" (Husserl 1992, p. 45). Through this process of coming together of individual traditions, no single tradition could claim for itself the status of an absolute foundation. Instead, it revealed a new need for such concepts that were able to describe our belonging to a particular tradition as well as its limitations. In addition to what Husserl called the idea of a "national-traditional" reason, there emerged the concept of "pure reason [...] through which the pure and absolutely objective world is first disclosed" (Husserl 1992, p. 347). Philosophy, in this sense, created a new division within the concept of reason itself. While our conscious life is attached to a particular tradition, it also connects us to the same world.

Now, it is important to note that the birth of philosophy-and consequently, the "primal establishment" of the idea of Europe-was as much a dismantling of a tradition as it was the beginning of a new one. As Husserl was keen to emphasize, the "founding act" of philosophy was not to be conceived as a simple institution, which, as in the case of geometry or physics, would have allowed a succeeding creation and accumulation of propositions. Instead, this idea contained within itself an element of negativity with regard to pre-philosophical practices. As Husserl put it, philosophy "emerges without a tradition in order to establish a tradition" (Husserl 1959, p. 320). Its teleological structure is something completely new-

[...] Philosophy wants to be "science", universal science of the universe; in all of its different systematic forms, it wants to be general according to the absolutely valid truth which binds all of those who are capable of intuitive evidence. (Husserl 1959, p. 320)

This special character of philosophy, Husserl argued, could not be described or explained in terms of a particular doctrine, thesis, or technique. Instead, philosophy understood itself in a critical relation towards all forms of traditionality on the basis of a new principle of justification binding all rational subjects in the same way. Instead of reproducing or imitating the tradition, philosophy turned its gaze to the general structure of traditionality as such: Why does culture appear in the form of a more or less unified tradition? What is the specific mode of meaning constitution that characterized intergenerational constitution of meaning? Additionally, why do we fail to understand each other although we share the same basic horizon, the world? Philosophy was radical because it was the first cultural practice that understood its own traditionality not as a given but as a question to be asked..$^{9}$

Understood in this ideal or spiritual sense, philosophy was of course by no means restricted to Greece. Of course, it emerged in the favorable generative conditions that prevailed in the Classical era, in a world that, to use the common expression of international relations theory, was essentially multipolar. As Deleuze and Guattari have argued, the city-states of Ancient Greece, especially Athens, seemed to be "at once near enough to and far enough away from the archaic eastern empires to be able to benefit from them without following their model" (Deleuze and Guattari 1994, p. 87)—the Hellenic world was not centered on a single ruling hegemony, but it was responsive to the multitude of cultures, habits, and practices. However, there is no factor that would limit this responsiveness to the Hellenic world, no reason why similar conditions could not prevail also in other circumstances. (We are only to think of Montesquieu's Persian Letters, its spirit of mockery targeted against the different traditions of Europe, combined with the "political sociology" of The Spirit of Laws that explained the multitude in national legal frameworks on the basis of arbitrary differences in climate rather than insurmountable differences in culture).

Thus, what Derrida considered as the basic "contradiction" in Husserl's analysis of Europe- "the refusal of an empirical definition of Europe ... and the presenting of philosophy as borne in the heart of certain men and as an original historical phenomenon"- 
was not a contradiction at all. Rather, it simply elucidated the basic understanding of the domain of the transcendental in Husserl's genetic phenomenology. Unlike Kant, who took the domain of transcendental as consisting of a priori (and thus "empty") logical functions of any possible consciousness, Husserl argued for the inextricable "mineness" of the transcendental ego. Instead of functioning as a formal condition of experience, the transcendental ego constantly individualizes itself in the living stream of consciousness; to use the Leibnizian phrase, it becomes a monad in "the unity of its living becoming, its history" (Husserl 1973c, p. 36). To speak of certain universal, a priori features of the transcendental ego (such as the phenomenon of time consciousness) does not conflict in any way with this individuation; rather, these features are only approachable as belonging to my personal experience. Therefore, it is with the idea of philosophy and its novel "stage" of rationality: it can only be approached based on its emergence in a particular tradition (in Husserl's narrative, the Greek one), but this does not reduce it into a mere empirical phenomenon.

Thus, "spiritual Europe", rather than denoting a mere "history of ideas" or simple geography, refers simply to this process of individuation where philosophical reason intersects with the development of culture, or becomes one of its guiding motives. The history of this figure, taken from the generative standpoint, is one of constant reorganization of limits; it is the constant sublation of national and cultural borders in the name of philosophical universalism, but also the creation of new frontiers on the basis of ethnic, national, and cultural differences, real or imagined. Husserl was well aware that the history of "Europeanization" of the world (which he treated to be a falsification of the original universalistic motive) had not been a peaceful, cooperative process but rather a one-sided enforcing of a single normative framework (e.g., the propagation of Christianity, liberal democracy, and free-market capitalism). To look for genuine examples of universalism, the critique of an existing tradition for the sake of a new one, we should perhaps look outside the political history of Europe; for instance, the refusal of tradition ("law", nomos) in St. Paul's writings, the critique of the naturality of polis by the Hellenic schools (primarily Cynics and Stoics), or Descartes' Meditations and his insistence "to demolish everything completely and start again from the foundations". In this regard, Husserl's understanding of the spiritual history of Europe coincides with Hegelian dialectics-it is not a simple accumulation of ideas but also one of negativity, of contesting a previous tradition.

\section{Conclusions}

In this article, I have discussed Derrida's reading of Husserl's concept of the spirit, particularly in the context of European teleology. As I have argued, Derrida's interpretation, while suggestive, was based on a clear misreading of Husserl's original argument. Unlike Derrida claims, Husserl did not equate Europe with the universal history of the human spirit as such. For Husserl, Europe was not to be understood in terms of a Hegelian end of history. Nevertheless, he treated the birth of philosophy as a fundamentally new avenue in the transcendental history of humankind-one which opened up the possibility of a completely new horizon of cultural production. It relied on a fundamentally new type of cultural accomplishment: ideas. For Husserl, the vocabulary of spirit and spirituality emerged exactly as a way of alleviating the fact that transcendental-ideal concepts, rather than being empty logical principles, are always born in a particular historical moment. It was exactly the concept of spirit that Husserl employed to emphasize the "contaminated" character of philosophical ideas: they too are embedded in a particular historical context and thus intertwined with the empirical history of a particular community.

This is not to say that Derrida's criticism of Husserl would have been without justification —or that Husserl could be defended against other types of critiques (such as Nietzsche and Heidegger). In the light of historical evidence, it is not clear at all that the birth of philosophy in Classical Greece signified such a significant transition in the history of humanity. Philosophy, too, was embedded in several pre-philosophical practices and could be understood rather in terms of continuation of the old than something completely 
new. What the vocabulary of spirituality emphasized, however, was that this process of idea creation was to be understood as fundamentally communal and intergenerational, as something that takes place only in a historical continuity of different generations. Instead of being hermetic by character, the philosophical community was defined by a fundamental openness toward other peoples. Translation, not one-sided propagation, was the language of philosophy. Husserl's late interpretations can be seen as coming very close to what Derrida later analyzed with the concepts of hospitality and radical otherness. These connections cannot be pursued here in more detail. However, they open up a fundamentally different kind of historical narrative to the one pursued by Derrida in his Of Spirit.

Funding: This article has been written with the support of the Academy of Finland funded Centre of Excellence in Law, Identity and the European Narratives, funding decision 312430 and 336677.

Institutional Review Board Statement: Not applicable.

Informed Consent Statement: Not applicable.

Data Availability Statement: Not applicable.

Acknowledgments: I want to thank the two anonymous reviewers for their constructive feedback.

Conflicts of Interest: The author declares no conflict of interest.

\section{Notes}

1 On the notions of "spirit" (Geist) and "spiritual" (geistig), see (Husserl 1973a, p. 112; Husserl 1952, p. 172ff.; Husserl 1976, pp. 114-17), passim.; (Husserl 1988, pp. 267-93).

2 On the notion of "spiritual [form of] Europe", see (Husserl 1976, pp. 318-21, 336, 549). Husserl also refers to the spiritual "space" (Raum) of Europe, see (Husserl 1992, p. 58).

3 The relation between Hegel's notion of spirit and Husserlian generativity has been explicitly discussed by (Steinbock 1998, pp. 163-76).

$4 \quad$ See, e.g., (Husserl 1976, p. 220; Husserl 1959, pp. 123, 151; Husserl 1966; Husserl 1973b, p. 469; Husserl 1973d, p. 321).

5 Moreover, this notion provided a means of approaching the problematic of "natural" and "human" sciences (Geisteswissenschaften)—a distinction that had been addressed widely by such philosophers as Dilthey, Windelband, Rickert, and Münsterberg (Ricoeur 1967, p. 68ff.).

6 Thus, from the perspective of relative lifeworlds, philosophy was as much an intellectual activity as it was, in the words of Deleuze and Guattari, a geo-philosophy—a form of thinking which necessarily entailed a specific "deterritorialization [...] the movement from territory to earth" (Deleuze and Guattari 1994, p. 86).

$7 \quad$ See, e.g., (Waldenfels 1997, p. 22).

8 (Husserl 1992, pp. 41-46). See also (Husserl 1976, p. 340; Husserl 1988, pp. 189, 194ff.).

9 See, e.g., (Waldenfels 1997).

\section{References}

Deleuze, Gilles, and Félix Guattari. 1994. What Is Philosophy? London: Verso Books.

Derrida, Jacques. 1987. De l'esprit. Paris: Galilée.

Derrida, Jacques. 1989. Edmund Husserl's Origin of Geometry: An Introduction. Translated by John P. Leavey Jr. Lincoln: University of Nebraska Press.

Derrida, Jacques. 1992. The Other Heading. Reflections on Today's Europe. Bloomington: Indiana University Press.

Derrida, Jacques. 2003. The Problem of Genesis in Husserl's Philosophy. Translated by Marion Hobson. Chicago: University of Chicago Press.

Derrida, Jacques. 2011. Voice and Phenomenon. Translated by Leonard Lawlor. Evanston: Northwestern University Press.

Hegel, G. W. F. 1975. Lectures on the Philosophy of World History. Translated by H. B. Nisbet. Cambridge: Cambridge University Press. Husserl, Edmund. 1950. Ideen zu einer reinen Phänomenlogie und Phänomenlogischen Philosophie. Edited by Walter Biemel. Erstes Buch: Allgemeine Einführung in die reine Phänomenologie. The Hague: Martinus Nijhoff Publishers.

Husserl, Edmund. 1952. Ideen zur einer reinen Phänomenologie und Phänomenologischen Philosophie. Edited by Marly Biemel. Zweites Buch: Phänomenologische Untersuchungen zur Konstitution. The Hague: Martinus Nijhoff.

Husserl, Edmund. 1959. Erste Philosophie (1923/4). Edited by Rudolf Böhm. Zweiter Teil: Theorie der phänomenologischen Reduktion. The Hague: Martinus Nijhoff. 
Husserl, Edmund. 1966. Analysen zur passiven Synthesis. Aus Vorlesungs-und Forschungsmanuskripten, 1918-1926. Edited by Margot Fleischer. The Hague: Martinus Nijhoff.

Husserl, Edmund. 1973a. Cartesianische Meditationen und Pariser Vorträge. Edited by Stephan Strasser. The Hague: Martinus Nijhoff.

Husserl, Edmund. 1973b. Zur Phänomenologie der Intersubjektivität. Edited by Iso Kern. Texte aus dem Nachlass. Erster Teil. 1905-1920. The Hague: Martinus Nijhoff.

Husserl, Edmund. 1973c. Zur Phänomenologie der Intersubjektivität. Edited by Iso Kern. Texte aus dem Nachlass. Zweiter Teil. 1921-1928. The Hague: Martinus Nijhoff.

Husserl, Edmund. 1973d. Zur Phänomenologie der Intersubjektivität. Edited by Iso Kern. Texte aus dem Nachlass. Dritter Teil. 1929-1935. The Hague: Martinus Nijhoff.

Husserl, Edmund. 1976. Die Krisis der Europäischen Wissenschaften und die Transzendentale Phänomenologie. Edited by Walter Biemel. Eine Einleitung in die phänomenologische Philosophie. The Hague: Martinus Nijhoff.

Husserl, Edmund. 1988. Aufsätze und Vorträge. 1922-1937. Edited by T. Nenon and H. R. Sepp. The Hague: Kluwer Academic Publishers.

Husserl, Edmund. 1992. Die Krisis der Europaischen Wissenschaften und die Transzendentale Phänomenologie. Edited by Reinhold N. Smid. Ergänzungsband. Texte aus dem Nachlass 1934-1937. The Hague: Kluwer Academic Publishers.

Kleingeld, Pauline. 2012. Kant and Cosmopolitanism. The Philosophical Ideal of World Citizenship. Cambridge: Cambridge University Press.

Ricoeur, Paul. 1967. Husserl: An Analysis of His Phenomenology. Translated by Edward Ballard, and Lester Embree. Evanston: Northwestern University Press.

Steinbock, Anthony. 1998. Spirit and Generativity. In Alterity and Facticity. New Perspectives on Husserl. Edited by Natalie Depraz and Dan Zahavi. Dordrecht: Kluwer, pp. 163-204.

Waldenfels, Bernhard. 1997. Topographie des Fremden: Studien zur Phänomenologie des Fremden. Frankfurt am Main: Suhrkamp. 